\title{
CAROLINE DOMMEN
}

Founder and Director of 3D -> Trade - Human Rights - Equitable E conomy, Geneva,

Switzerland. She has a M asters Degree in Law and Development from the University of London.

\section{ABST RACT}

This article focuses on ways that human rights advocates can ensure that trade and trade rules promote rather than undermine human rights. The article concludes that an effective way to achieve respect for human rights in international trade policy is through engaging with trade policy-makers of national governments, and show the positive role a human rights contribution can play in ensuring a fair and democratic international trading system. The article points out that human rights defenders share concerns about trade with development groups, women's rights advocates, environmentalists and others already working on trade, and suggests that human rights advocates demonstrate, through applying the relevant human rights accountability mechanisms, how they can make a positive contribution to making trade more equitable and human rights-friendly. [O riginal article in English.]

\section{KEYWORDS}

Trade - H uman rights - WTO - D evelopment 


\section{TRADE AND HUMAN RIGHTS: TOWARDS COHERENCE*}

Caroline Dommen

In the last few years, there have been many claims about whether or not trade liberalization enhances - or undermines - human rights, and about whether trade agreements should do more - or nothing - to promote human rights.

These claims come from various quarters: human rights advocates who want to ensure that trade and trade-related rules do not undermine the enjoyment of human rights (the "coherence" perspective), those who want to see trade sanctions used as tools to ensure respect for minimum standards of human rights (the "conditionality" perspective), believers in free trade and developing countries who fear that human rights standards might be applied in a way that works against freetradeand thus undermineeconomic well-being, and development campaigners who see "human rights" as a useful slogan.

All of these very different actors bring very different perspectives to what they mean by "trade and human rights" and thus much confusion surrounds discussions on these topics.

This article will focus on how human rights advocates can ensure that trade and trade rules are developed in a way that promotes rather than undermines human rights. After looking at the human rights-inconsistent process of trade negotiations, it will consider ways in which application of trade rules risk undermining human rights. This article will then describe some ways to ensure that human rights are protected and promoted in international trade, and caution against some initiatives that could be counterproductive.

* I wish to thank J uana Kweitel for her assistance in preparing this article for publication. Responsibility for opinions expressed and any errors that may remain lies entirely with the author. 
The article concludes that an effective way to achieve respect for human rights in international trade policy - especially that policy developed and applied in the World Trade 0 rganization (W TO ) - is through raising human rights concerns with the trade policy-makers of national governments, particularly through showing the positive role a human rights contribution can play in ensuring a fair and democratic international trading system.

\section{Lack of transparency, narrow participation: human rights inconsistent}

Trade policy is infamous for being untransparent and undemocratic. Lack of transparency and participation do not in themselvesnecessarily lead to human rightsharmful outcomes. But they often do. They also stand in direct contrast to human rights principles, such as the right of everyone to take part in the government of their country, embodied in Article 21 of the U niversal D eclaration of H uman Rights; the right of access to information, embodied in Article 19 of the International Covenant on Civil and Political Rights (ICCPR); and citizens' rights to participatein the conduct of public affairs set out in Article 25 of the ICCPR.

While within the World Trade 0 rganization there have been improvement in access to documents and meetings, many key documents are still not made public until they cease to be relevant, if they are made public at all. And progress within the World Trade 0 rganization has been offset by the increasing number of bilateral trade negotiations which areso secretivethat they maketheW TO seem positively translucent in contrast.

Indeed, bilateral trade negotiations are almost invariably negotiated away from the public eye, and often progress so quickly that it is impossible for civil society groups - and sometimes even government ministries other than trade or the highlevel political negotiators - to comment on draft texts or bring their expertise on specific issue-areas to the negotiations. An example can be found in Thailand. As the Thai group FTA Watch reports, in the Thai-US negotiations for a bilateral trade agreement, the U nited States demanded that the Thai government verbally agree to keep the process of negotiations secret. ${ }^{1}$ The Thai government signed another trade agreement (with Australia) without the involvement of Parliament and without disclosing the content of theagreement to the public until after the pact was concluded, and then only in English.

In addition to being contrary to the international human rights standards set out above, this is contrary to the Thai Constitution, which encourages public

1 See FTA Watch Thailand, "Thailand's Free Trade Agreements and Human Rights Obligations" ( $M$ arch 2005). Available at <www.ftawatch.org/autopagel/show_page. php?t=21\&s_id=8\&d_id $=8>$. Last access on 6 September 2005. 
participation in policy decision making and monitoring the state's exercise of power, ${ }^{2}$ and U nited States trade rules which aim to obtain wider and broader transparency in thenegotiating process. ${ }^{3}$ This situation is replicated across many of the bilateral trade agreements negotiated between industrialized and developing countries.

This lack of transparency facilitates human rights-inconsistent outcomes. In many cases, it gives a stronger role to business than public interest groups, as governments will tend to consult business groups and put forward their interests more than those that civil society is defending. ${ }^{4}$ For instance, the interests of the Pharmaceutical Research and M anufacturers of America (PhRM A) are reflected in almost all the recently-adopted US bilateral trade agreements, ${ }^{5}$ resulting in putting affordable medicines out of reach of many, contrary to the right to health principle of facilitating access to medicines. ${ }^{6}$

In addition, broader transparency of the negotiations could promote the accountability needed to help developing countries achieve trade agreements that are more development-friendly, and that serve the needs of the most vulnerable members of their population, consistent with human rights principles. This is particularly the case in bilateral trade negotiations where power imbalances are significant and developing countries are often pressured into agreements that are not in their own interest.

2. Section 76 of The Constitution of the Kingdom of Thailand says: "The State shall promote and encourage public participation in laying down policies, making decision on political issues, preparing economic, social and political development plans, and inspecting the exercise of State power at all".

3. Bipartisan Trade Authority Bill 2002, Section 2102 (b)(5).

4. For a discussion of the representation of business interests in the WTO, see C. Dommen, "The WTO, International Trade, and Human Rights", in M. Windfuhr (ed.), Beyond the Nation State Human Rights in Times of Globalization (Global Publications Foundation, 2005). Available at $<w w w .3 \mathrm{dthree.}$. rg/en/page. php? I D page=13\&IDcat=5>. Last access on 6 September 2005.

5. See M. A sif I smail, “ Exporting P rices, Drug M akers'Trade Group M akes the Industry's P riorities US Trade Policy", (Center for Public Integrity, Washington DC, July 2005). Available at <www.bilaterals.org/article.php3?id_article=2233>. Last access on 6 September 2005.

6. See UN Press Release, "US-Peru Trade Pact Negotiations: Special Rapporteur on Right to Health Reminds Parties of Human Rights Obligations" (J uly 2005). Available at <www.unhchr.ch/ huricane/huricane.nsf/view01/502C4F 87F 9FF 119B C125703D00396440? opendocument>. Last access on 7 September 2005. For a discussion of the benefits and disadvantages of bilateral trade agreements, with a focus on the impact of Intellectual Property rules on access to medicines, see Hamed EI-Said \& M ohammed EI-Said, “TRIPS, Bilateralism, M ultilateralism \& Implications for Developing Countries: J ordan's Drug Sector" ( M anchester J ournal of I nternational E conomic Law, A pril 2005). Available at <www.bilaterals.org/article.php3?id_article $=2192>$. Last access on 6 September 2005. 
But even in theW orld Trade 0 rganization, where broad developing country membership does help the economically weaker participants to negotiate together and resist pressures, developing countries have difficulty in having their interests taken into account. The W TO is in theory democratic as each member has an equal vote. But in reality, developing countries have difficulty in participating as equals. ${ }^{7} O$ ne reason for this is lack of capacity. $M$ any of the poorest countries are not even able to have World Trade 0 rganization representatives in $G$ eneva. 0 thers only have one part-time delegate to cover the whole breadth of W TO issues, and only a handful of trade policy staff in their capital. In contrast, Japan has 23 World Trade 0 rganization delegates in its G eneva mission, and the USA has 14, as well as large and well-resourced trade offices in Tokyo and Washington DC respectively. ${ }^{8}$

Added to this, poor countries are often obliged to make concessions in order to trade with richer countries. So in practice, new trade rules are weighted in favor of the rich, and do not necessarily reflect the long-term interests of the poorest countries and their inhabitants. Even staunch World Trade 0 rganization supporters agree that, during the negotiations creating the W TO , developing countries agreed to substantially more obligations than developed countries did. ${ }^{9}$ Subsequently, developed countries have demonstrated little political will to address issues dear to developing countries. This is exacerbated by the fact that the World Trade O rganization Secretariat, supposed to be neutral, often acts in a way supportive of what industrialized countries ask for, against developing countries' wishes. In June 2005, for instance, both theW orld Trade 0 rganization Secretariat and the C hair of the services negotiations took strong positions against proposals advocated by many developing countries. ${ }^{10}$

Although developing countries have improved their collective strength in the World Trade 0 rganization in recent years, and have enjoyed some successes, both in terms of substance and of process, there is a flip side to this success. As developing countries have participated more meaningfully in theW TO 's work and succeeded in having their concerns taken into account, there is a move of trade decision-making away from G eneva, such as to WTO "mini-ministerial", unofficial meetings hosted

7. A 1998 study showed that of the 97 developing countries that were then members of the WTO, 56 do not participate effectively in its work. See Constantine M ichalopoulos, "The Participation of the Developing Countries in the WTO" (World B ank Policy Research Paper, 1998).

8. See Fatoumata J awara \& Aileen Kwa, Behind the Scenes at the WTO - The Real World of International Trade Negotiations (L ondon \& N ew York: Zed Books, 2003).

9. J effrey Schott, "WTO 2000: Setting the Course for World Trade" (1998).

10. Alexandra Strickner \& Carin Smaller, "Formula One Racing: Who's Going to Win the Grand Prix?" (IATP/TIP Geneva U pdate, J une 2005). 
by a W orld Trade $O$ rganization member, which play a crucial rolein determining the outcome of negotiations. In general, only selected countries' M inisters are invited to these meetings, and powerful economies play a disproportionate role in them.

Just as worryingly, trade decision-making istaking place in bilateral or regional trade agreements. This move away from multilateralism and collective public scrutiny causes the most significant human rights concerns described throughout this article.

The shift away from one multilateral forum to a plethora of bilateral ones is why it is important to seek accountability from national governments on their trade policy positions, by demanding, for instance, that they make all their trade negotiating positions public, and ensure that they are aware of the human rights implications of the proposals.

\section{WTO rules nationally: limiting policy space}

The most common way that rules developed in the World Trade 0 rganization affect human rights is through limiting governments' ability to regulate or to take other measures to promote or protect human rights at the national level. Indeed, in promoting "free trade" the WTO and bilateral agreements seek to do away with possible regulatory interferences with thefreeflow of goods and services, thuslimiting governments' ability to regulate in favor of development, environmental protection, or to defend vulnerable groups. This has given cause for particular concern regarding essential elements of livelihood such as food or health, ${ }^{11}$ and provision of basic services such as education, health care or water. ${ }^{12}$

The list of cases where World Trade 0 rganization and other trade rules have hindered enjoyment of the rights to food, health, education, housing or others would belong. Also, many of these cases do not cometo public light or arelinked in complex ways to other aspects of economic policy, making it hard to distinguish the role of trade agreements. This article will look at one issue area where W TO -related rules could limit countries ability to take measures that favor human rights: WTO rules on trade in services.

11. For a discussion relating to agriculture trade liberalization and human rights, see $3 D \&$ IATP, "Planting the Rights Seed - A H uman Rights Perspective on A gricultureTrade and the WTO" (2005). A vailable at <www. 3 dthree.org/en/page. php? I D page $=38 \& I$ D cat=5>. L ast access on 7 September 2005 .

12 See also Caroline Dommen, "Raising Human Rights Concerns in the World Trade Organization - Actors, Processes and Possible Strategies" (Human Rights Quarterly, vol. 24, pp. 1-50, 2002); and OHCHR, "Human Rights and Trade" (paper prepared for the $5^{\text {th }}$ WTO M inisterial Conference in Cancún, 2003). Available at <www.unhchr.ch/html/menu2/trade/index.htm>. Last access on 7 September 2005. 


\section{Liberalization of trade in services and governments duty to regulate ${ }^{13}$}

The realization of human rights requires effectivenational policies. The policies required will differ from country to country: one-size fits-all solutionsdo not exist. G overnments will need the regulatory space and flexibility to tailor domestic regulatory policies to the needs and particularities of the country, society and human right in question. International rulesand negotiation son liberal ization of trade in services risk curtailing governments' policy space and flexibility. Although services are included in most bilateral tradeagreements, theglobal framework remainstheWorld TradeO rganization. This section will therefore focus on services trade liberalization through the World Trade 0 rganization.

A service isa result of human activity which is not a tangiblegood. Liberalization means that foreign and domestic service providers can compete to provide services. The scope of services trade liberalization through the WTO and other trade agreements is vast, ranging from accounting and advertising to telecommunications, tourism or transport. Liberalization can have - and has had - implications for access to basic services and thus for human rights in areas such as education, health care, job security or access to water. Rules on services trade liberalization, however, can reach further within a governments' regulatory space and affect human rights in that way, as the U S-G ambling case discussed below shows.

The World Trade O rganization requires neither privatization nor deregulation of services, nor does the WTO require any country to open up any particular service sector to international competition. So why is the World Trade 0 rganization held responsible for human rights concerns arising from services liberal ization? To help us find the answer, this article will examine some human rights dimensions of these three points - privatization, deregulation, services covered - in turn.

Services were first introduced into the multilateral trading system in the late 1980s, resulting in the adoption of the General Agreement on Trade in Services (GATS) in 1995, as an integral part of the WTO Agreement. World Trade O rganization efforts to liberalize trade in services are part of a broader global trend towards increasing private sector participation (and increasingly, participation of large and powerful multinational corporations) in the provision of state-like functions, provoking competition in areas that were once under the responsibility of government as service supplier.

Liberalization does not explicitly require privatization of any particular service sector. In practice, however, allowing competition in a service sector implies the elimination of a monopoly, including public monopolies. This process is frequently

13. F or a more detailed discussion of how rules on liberalization of trade in services affect human rights, see 3D \& Forum-Asia, "P ractical Guide to the WTO for Human Rights Advocates" (2004). Available at <www.3dthree.org/en/complement. php? I Dcomplement=36>. Last access on 7 September 2005. 
tantamount to privatization. In the real world, therefore, thereareclear links between liberalization and privatization, but international trade agreements including the W TO 's, shy away from explicitly expressing any preference for private over public provision of services.

In some sectors, such astelecommunications in Asia, serviceshavegreatly improved after privatization and liberalization: quality and avail ability increased and pricesdropped. In others, though, atwo-tiered system has emerged, with ahigh-qual ity segment available to those who can afford it, and an underfinanced government-provided segment for the poor. In some cases, privatization has put services out of reach of poor peoplealtogether: in Ghana for instance, even water prices which the government and the World Bank considered to be below the market rate are beyond the means of most families. Indeed, the private sector being driven by commercial, profit-oriented objectives, private competition in basic serviceprovision is not themost effectivemeans of ensuring universal access to services which are essential but not lucrative.

H uman rights law does not oblige States to be the sole provider of essential services. H owever, it does requireStatesto guarantee essential service supply, especially to the poor, vulnerable and marginalized. The increasing frequency of two-tiered availability of services defacto discriminates against the most vulnerable or marginalized sectors of a population, contrary to human rights. Indeed, the non-discrimination principle, central to human rights law, prohibits discrimination on the basis of the ability to pay for basic services.

In addition to making access to essential services harder, privatization and liberalization can make it harder for governments to regulate. In human rights terms regulation is not only a need but also a duty. Indeed, human rights law requires States to take appropriatelegislative, administrative, budgetary, judicial and other measures to fulfill human rights.

Like other trade rules, those on services aim to eliminate obstacles to trade, including possible regulatory interferences. Whilebarriersto tradein goods areusually imposed at national borders (for examplethrough tariffs), barriers to trade in services are more diverse. In addition, barriers to trade in services frequently affect core areas of domestic regulation, such as licensing standards (such as facilities licensing for clinics and laboratories, or waste disposal permits), minimum professional standards, subsidies for providers of essential services, or social objectives that foreign investors and service providers must meet.

There is a practical and a legal aspect to governments' difficulty in regulating in the public interest to fulfill their role as primary duty bearer of human rights. The practical dimension relates to the difficulty of regulatean increasingly largeand powerful private sector. In the health sector, for instance, the World Trade 0 rganization has indicated that private companies can subvert health systems through political pressure and "regulatory capture", namely the co-opting of regulators to make regulations more favorable to private companies. When the service provider is foreign, it is even 
harder for a government to impose conditions, particularly when the country in question is keen to attract foreign investment.

The legal aspect relates to the regulations that $G$ eneral Agreement on Trade in Services will allow. While GATS does recognize the right of WTO M embers "to regulate, and to introduce new regulations, on the supply of services within their territories in order to meet national policy objectives" it sets limits on government regulations, and can thus challenge national regulatory prerogatives.

A recent WTO Appellate Body ruling raised important issues in this regard: the US-Gambling case ${ }^{14}$ Antigua and Barbuda had brought a challenge to the U S internet gambling ban to the World Trade 0 rganization dispute settlement system, saying it was a violation of the US' General Agreement on Trade in Services commitments. TheW TO Appellate Body ruled that in the case of internet gambling, the U S ban is excused by the "public morals" exception in G ATS, which allows countries to derogate from the provisions of the agreement. H uman rights advocates can be encouraged that this decision could allow other countries to derogate from G eneral Agreement on Trade in Services obligations in the future, to uphold the public interest objectives that GATS recognizes. ${ }^{15}$

N evertheless, concerns remain. A significant oneisthat theAppellateBody's broad interpretation of what restrictions are prohibited under GAT S may threaten the validity of many domestic service regulations that were so far considered to be allowable. ${ }^{16}$

Another lies in bilateral trade agreements provisions relating to services. CAFTA for instance (the Central American Free Trade Agreement, the recently-concluded agreement between the US on the one hand, and several central American countries on the other) includes provisions that allow foreign investors to challenge government measuresthat areinconsistent with theAgreement. CAFTA doesnot contain an exception similar to General Agreement on Tradein Services "public morals" exception, so aC entral American-based company might succeed in a legal challenge to strike down public interest measures, such as bans like the U nited States internet gambling one. ${ }^{17}$

\footnotetext{
14. "U nited States - M easures Affecting the Cross-B order Supply of Gambling and B etting Services (Complaint Brought by Antigua and Barbuda)". Report of the Appellate Body, WT/DS285/AB/R, issued on 7 A pril 2005.

15. These include measures necessary to protect public morals or to maintain public order; or necessary to protect human, animal or plant life or health. See GATS, Article XIV: General Exceptions.

16. J oost Pauwelyn, "WTO Softens Earlier Condemnation of US Ban on Internet Gambling, but Confirms B road Reach into Sensitive Domestic Regulation" (A pril 2005). Available at <www.asil.org/ insights/2005/04/insights050412.html>. Last access on 7 September 2005.
}

17. Peace through I nteramerican Community Action (PICA), "CAFTA J eopardizes M aine's Gambling Regulations" (J uly 2005, on file with the author). 
A particular aspect of human rights-based concerns about GATS relates to public services. Legitimacy of governmental regulation in this area, which coversbasic services, is especially uncertain - and it is unclear whether it comes under the scope of $G$ eneral Agreement on Trade in Services (which would mean that governmental regulations including thosedesigned to promotethe realization of human rightssuch assubsidies to governmental providers would be prohibited) or not. Indeed, national regulations are subject to GATS' general obligations, including the prohibition on discrimination between different countries' service providers.

Suppose that the government of a W TO member (country A), has not made any commitments to liberalize trade in education services and runs most schools, although private education is also available. Faced with a shortage of teachers in the public schools, and the adverse impact of this shortage on the right to education, country $A$ decides to enter into a bilateral agreement with country $B$ to allow teachers from $B$ special derogations from immigration requirements so that they can teach in country A. In spite of the fact that country A has not made commitments in the area of education, the agreement with country B might be found to violate the GATS non-discrimination principle, as it gives preferential treatment to service suppliers from country $B$ over country $C$. The preference granted to $B$ might have a genuine public policy purposeif thelanguagespoken in country $B$ is thesameas in country $A$, for instance, or if they have more of a shared culture and history than A does with C.

H owever, in thisscenario, if education services do not fall under $G$ eneral Agreement on Trade in Services, there would beno violation. The reason why it is unclear whether education or other public services come under GATS is that the agreement does not apply to services "supplied in the exercise of governmental authority". TheAgreement defines this as "any service which is applied neither on a commercial basis nor in competition with one or more servicesuppliers" - but the actual scope of this provision is clear to none, even theworld'sleading G AT S experts. Indeed, theincreasing supply of government serviceson a commercial basis has challenged the clear distinctionsbetween governmental and non-governmental service provision.

Another way General Agreement on Trade in Services might reduce a country's flexibility to regulate in the public interest is through limiting a governments' ability to provide economic measures in favor of disadvantaged groups. H uman rights law requires governments to take steps to ensure enjoyment by particularly vulnerable groups of their human rights. Some governments protect steps they take to this end in their GATS commitments. N ew Zealand for instance, exempts from its GATS obligations "current or future measures at the central and sub-central levels according more favorable treatment to any $M$ aori person or organization in relation to the acquisition, establishment or operation of any commercial or industrial undertaking". Australia and M alaysia do much the same for their indigenous peoples.

Pro-GATS advocatesmight rely on theseexamplesto arguethat G eneral Agreement on Trade in Services does not limit a government's ability to pursue public interest 
objectives, since countries have a lot of scope to choose which commercial sectors to commit to GATS and which sectors to exempt. Countries who need social policy exemptions, they argue, can carveout the policy spacethey need to pursuethem. H owever, a country that has a policy to facilitate access of a disadvantaged group to a particular service, but omitted to exempt it from General Agreement on Trade in Services, may find itself in contravention of GATS, as might a country that introducessuch a policy in thefuture In addition, the political dynamics, power imbalancesor simply thecomplexity of trade negotiations sometimes lead countries to make commitments in areas in which liberalization or deregulation go against their national interests. And this does not only affect small countries: the US-Gambling case was based on a commitment that US trade negotiators had apparently made erroneously, a mistake that went undetected for nearly 10 years until Antigua and Barbuda's WTO challenge.

This points to another key concern about $G$ eneral Agreement on Trade in Services, which is its "lock-in" effect. O nce a country has made a GATS commitment, it is virtually impossible to change, even if later circumstances require such change. Reversing the Agreement commitments is technically permitted, but governments can only do so by negotiating "compensation" for all affected trading partners, which can be prohibitively costly. This means that if subsequent events reveal negative social or economic effects, it may betoo lateto takecorrectiveaction, and that a government may be curtailed from taking steps to address a social problem that only becomes manifest after the government has made GATS commitments.

In short, it would appear that governments retain their freedom to regulate only to the extent that the regulations they adopt are compatible with GATS. The threat of being brought beforeaW orld Trade 0 rganization dispute settlement panel because of a new regulation affecting foreign service providers could have a chilling effect on governments' inclination to regulateto promotehuman rights or in thepublic interest. From a democracy and accountability perspective there is an additional concern: in thefinal instancethejudgment as to whether a domestic regulation is G ATS-compatible will be made not by governments but through WTO dispute settlement. And the panels mandate is to apply trade law - not to ensure the protection of the public interest in WTO member countries.

N egotiations to further liberalize services are currently under way in the WTO as well as in bilateral agreements, and many countries are coming under considerable pressure to liberalize more service sectors, or to eliminatelimitations on their existing commitments. M oreover, developing countries are being asked to make GATS liberalization commitments across such a broad range of service sectors that they are unable to analyze what the potential losses of benefits of such liberalization would be, let alone request access to industrialized countries' service markets. ${ }^{18}$

18. See for instance "Statement by J amaica to the WTO Trade Negotiations Committee" (28 J uly 2005 , on file with the author). 
From a human rights perspective, it is important that countries not commit new sectors under GATS until their human rights effect has been evaluated. GATS itself provided that a comprehensive assessment of theimpacts of services trade liberalization should havebeen undertaken before2000, but thisobligation remainsunfulfilled, much to thedissatisfaction of developing countries. African tradeministers, for instance, noted in June 2003 that the "Services Council has not satisfactorily met the requirement of carrying out theassessment of tradein servicesasstipulated in the GATS". Representatives of Latin American countries, and N G O saround theworld havevoiced similar concerns.

$H$ uman rights advocates have constructively added their voices to calls for assessment of the potential and actual impact of services policies, on thegrounds that these are fundamental to ensure the most appropriate policies and regulations for development, and for human rights. TheH igh Commissioner for $\mathrm{H}$ uman Rights has for instance recognized that States havetheresponsibility to ensure that commitments they make in other areas, including trade, does not reduce their capacity to set and implement national development policy. In a detailed study of services trade liberalization and human rights, the H igh Commissioner has concluded that human rights requirea constant examination of tradelaw and policy as it affectstheenjoyment of human rights, and that assessment is a major means of avoiding theimplementation of any retrogressive measure that reduces the enjoyment of human rights. ${ }^{19}$

\section{Rights in: upholding human rights in trade}

H uman rights advocates have an important task ahead of them to ensure that trade and trade rules respect promote and fulfill human rights. This section will indicate some points worth bearing in mind to ensure that efforts to mainstream human rights into trade agreements are successful.

First, it is essential to be clear about what we really want when we talk of human rights mainstreaming. This article assumes that what human rights advocates want is that international trade and traderules, including thosedeveloped and applied through theWTO, support rather than threaten human rights. H ow best then to achieve this?

Some human rights advocates call to abolish theW orld Trade 0 rganization as the solution to human rights-inconsistent trade policies. 0 thers call for adding the words "human rights" in WTO texts or other trade agreements. This section will argue that these calls are misguided, and that the best way to ensure that trade and trade rules promote human rights is to broaden the focus of the human rights lens from the World Trade O rganization, to integrate the human rights concerns of

19. Report of the High Commissioner, "Liberalization of Trade in Services and Human Rights" (UN SubCommission on the Promotion and Protection of Human Rights, E/CN.4/Sub.2/2002/9, 25 J une 2002). Available at <www.unhchr.ch/huridocda/huridoca.nsf/(Symbol)/E.CN.4.Sub.2.2002.9.En?Opendocument>. Last access on 7 September 2005. 
non-discrimination, monitoring, democratic participation and accountability at each step of the process of making and applying trade policy. This section will point out some effective ways in which human rights advocates can bring their experience to support efforts to promote a fairer and more human rights consistent international trading regime.

TheW orld Trade $O$ rganization is often accused of being the cause of economic injustices; there no shortage of examples of unfair W TO rules and processes. But even amongst critics, views differ sharply as to whether abolishing the WTO would be the solution to the problem. Some argue that the W TO is so deeply flawed that it is beyond reform and should thereforebeabolished. O thers however point out the importance of a multilateral framework for international trade, as only a multilateral framework can help insulate the small economies from the strong.

Indeed, the process and content of regional and bilateral trade agreements have provided a glimpse of how trade rules developed outside the multilateral framework are a far worse threat to global economic equity and enjoyment of human rights than the World Trade 0 rganization system. The way these agreements are negotiated is not only more secretive than the WTO, but imbalances of power are more extreme and the outcomes even less balanced and harmful to the public interest than what comes out of the World Trade O rganization. As G eorge M onbiot, a vocal critic of liberalization has recently said, the "only thing worse than a world with the wrong international trade rules is a world with no trade rules at all", ${ }^{20} \mathrm{H}$ e thus makes a plea not to scrap the World Trade 0 rganization, "but to transform it into a Fair Trade 0 rganization, whose purpose is to restrain the rich while emancipating the poor".

Some human rights advocates have called for inclusion of the words "human rights" in World Trade 0 rganization texts. This is a dangerous route for human rights, for three main reasons. First, the "no explicit reference" starting point in theW TO / human rights debate has been used to support fundamentally opposing views. Those who do not want to see human rights discussed in the World Trade O rganization declare that since the legal texts are silent on the issue, the WTO has no human rights-related mandate or obligations. T hose who want to see the W TO held accountable to human rights standards say that explicit rightslanguage should be brought into its text. Both seem to assume that the only way that the World Trade 0 rganization could be held accountable to human rights standards would be if human rights were explicitly mentioned. The implication is that until the words "human rights" are explicitly included in W TO texts, the World Trade 0 rganization will have no human rights mandate.

20. George M onbiot, "I Was W rong about Trade", (The Guardian, UK, 24 J une 2003). Available at $<$ www.monbiot.com>. Last access on 7 September 2005. 
Given the difficulty that W orld Trade 0 rganization members have of agreeing on even the simplest matters, changing the W TO legal texts might take a long time, and be extremely time-consuming. This is particularly the case given that many W orld Trade O rganization professionals still equate theterm "human rights" with "labor standards" and strongly resist expanding theW TO 's mandate to either. The time involved is the second reason why seeking to insert the words "human rights" into W TO texts would be a perilous undertaking. Because the ultimateand real - objective of work on human rights in the World Trade 0 rganization is to ensure that economic actors go beyond lip service to human rights, and effectively promote and protect these rights in their trade dealings, a change in WTO wording is unlikely to be the best use of human rights advocates time.

A third reason why including human rights wording in World Trade 0 rganization texts may not be a satisfactory outcome can be drawn from the experience of the environmental movement. Environmental issues began being discussed in earnest by the international trade community since the early 1990s; so environmental activists have a ten-year trade policy head start on their human rights advocates. R eferences to the environment were al ready present, if somewhat timid in the $1995 \mathrm{M}$ arrakesh Agreement that established the World Trade $O$ rganization. By the time of the $D$ oha $M$ inisterial Conference such references were frequent: the $D$ oha $M$ inisterial $D$ eclaration contains many references to the environment.

Yet almost no environmentalists are happy with the mandate crafted by trade officials, nor with the way that negotiations on the environment have been going in the World Trade Organization. Importantly, many environmental ists are now lamenting that bringing environmental issues formally into the W T O 's ambit has given the World Trade 0 rganization a large role in developing the issues. Based on this experience, experts on trade and the environment advise human rights advocates to ensure that any recognition of human rights and related values in the World Trade 0 rganization insulates those values from the trade regime, in order to avoid giving the WTO too much competence on human rights-related issues. ${ }^{21}$ In a similar vein, other public interest groups are seeking to reduce the W TO 's reach, and limit its activities strictly to regulating the technical aspects of trade. ${ }^{22}$

21. 3D -> Trade - Human Rights - Equitable Economy and Rights \& Democracy, "Towards Development: Human Rights and the WTO Agenda" (report of a panel discussion held during the WTO Ministerial Conference in Cancún, September 2003). Available at <www.3dthree.org/en/ page. php? IDpage=21\&IDcat=5>. Last access on 7 September 2005.

22. See International Gender and Trade Network, "I GTN at Cancún", calling for reduction of the scope of the WTO to specific trade issues (2003). Available at <www.igtn.org/page/404>. Last access on 7 September 2005. 
Assuming that when asking that human rights be mainstreamed in trade, human rights advocates want international trade and trade rules, including those developed and applied through theW TO , to support rather than threaten human rights, the discussion in this section so far points to the fact that mainstreaming would best be achieved by applying human rights tools to trade policy at the points at which it is made and applied, rather than bringing human rights into the World Trade O rganization.

As the previous sections have shown, the processes through which policy space for public interest regulation is reduced take place not just in the World Trade O rganization but also through bilateral agreements, and the way in which trade agreements are implemented at the national level. We have also seen that when the economic powers - whether countries or private business - are unable to attain their aims through the WTO, they move away from the multilateral forum to bilateral or regional trade negotiations, where they can exert more pressure, and often do so more privately. This pleads in favor of maintaining the spotlight on the national level, as this is where trade policy is formulated and applied, whether the rules are established in the World Trade 0 rganization or elsewhere.

Also, while devoting their attention to the WTO, human rights advocates concerns about trade have tended to let the human rights machinery languish in the background. Yet human rights rules and implementation mechanisms are a forceful basis for ensuring that trade and trade rules are equitable, work in the public interest and support rather than threaten human rights.

Paul H unt, U N Special Rapporteur on the Right to $\mathrm{H}$ ealth, has for instance pointed to ways that human rights can play a positive role in defining national trade policies that are equitable, attentive to the particular needs of the most vulnerable, and respectful of human rights. He has demonstrated how a right to health-based analysis can, in relation to essential drugs, help to identify practical and precise policy interventions to ensure enjoyment of the medicines element of the right to health. This includes ensuring that an essential drug is available in a particular country. To this end, a developing country should use available TRIPS flexibilities to ensure availability of low-cost versions of the drug. The drug must be accessible to all within the country, especially those living in poverty. This might call for creative thinking about delivery mechanisms such as mopeds for nurses, and could also require a country to avoid imposing import duties that make that drug inaccessible to the poor. Finally, an essential drug should be of good quality, which also implies that a country must havea system for monitoring and checking essential drug quality. ${ }^{23}$

23. For a more detailed analysis, see 3D -> Trade - Human Rights - E quitable E conomy and Rights $\&$ Democracy (op. cit., note 21 ). 
The $\mathrm{H}$ igh Commissioner for Human Rights has also drawn attention to ways human rights can be applied in the trade context. The 2002 report on trade in services, for example, says that the human rights approach to assessment of services trade liberalization introduces a methodology for assessments that promotes popular participation and consultation of those affected by liberalization - the poor, peopledependent on public services, small businesses, industry groups, as well as social, trade and finance M inistries. The report adds that a human rights approach to assessments emphasizes transparency and accountability so that the outcomes of assessments and negotiation processes in trade fora are open to public scrutiny. ${ }^{24}$

H uman rights advocates can further demonstrate the positive role they can play by participating in the development and formulation of trade policy at the domestic level. In some countries, coalitions of civil society groups al ready intervene in the formulation of trade policies, but - not counting trade unions human rights groups rarely participate. Participation of human rights groups in these processes would not only broaden the range of stakeholders represented, but would improve understanding amongst human rights advocates of trade policy issues.

Even when thetrade issues at hand are complex, an approach based on human rights can make a significant contribution through very simple steps. O ne such step would involve asking the trade ministry what steps it is taking, in its trade negotiations, to ensure that it is not reducing its policy space and flexibility to adopt measures for the protection of human rights. In the area of health, for instance, human rights advocates could ask the government trade officials whether they have ensured that proposals in areas such as intellectual property or services do not threaten enjoyment of the right to health.

If the information is not public, or if the response from government officials is that they do not know, human rights advocates can remind them of the human rights obligation to permit people to participate in decision-making on issues that concern them, and of the human rights obligation to monitor the human rights situation in their country in order to ensure that policies adopted promote human rights. H uman rights advocates should also remind those responsible for governmental trade policy of the duty to ensure non-discrimination in the enjoyment of human rights. This implies that if a particular trade liberalization

24. OHCHR (op. cit., note 12). The Human Rights Commission Working Group on the Right to Development has also emphasized the necessity of introducing and strengthening human rights standards and principles in undertaking impact assessments of trade and development rules and policies. See "Right to Development", Report of the Working Group on its sixth session (2005). Available at <www.ohchr.org/english/bodies/chr/docs/61chr/E.CN.4.2005.25.pdf>. Last access on 7 September 2005. 
policy discriminates against a particular sector of the population - and there is considerable evidence demonstrating that trade liberalization frequently has adverse effects on women ${ }^{25}$ - it will be inconsistent with human rights law. As the $\mathrm{H}$ igh Commissioner for H uman Rights has pointed out, respecting the human rights requirement to avoid discrimination means not only protecting individuals and groups against overt discrimination, but also not leaving certain individuals and groups out of the trade picture. ${ }^{26}$

Reminding trade policy-makers of the obligation to refrain from discrimination is al so a way of making trade-offs explicit. Public acknowledgment of who is being favored by a particular trade policy choice is an essential prerequisite for holding economic actors, including actors from the private sector, accountable for their actions and for possible adverse social effects of the private ben efits they might derive from a particular trade policy.

As $\mathrm{M}$ ary Robinson, former $\mathrm{H}$ igh Commissioner for $\mathrm{H}$ uman Rights has pointed out, increased participation by those affected contributes to trade policy that is more transparent, accountable and responsive to the needs of the people it is said to serve, as well as being more sustainable and more legitimate. ${ }^{27}$ Experience in many countries confirms this. U ganda, for instance, has a process for civil society participation in national trade policy formulation, and an official from the government Trade $M$ inistry recently said that "disadvantaged groups in this country like small farmers are ultimately affected by the economic and trade policies that are formulated. It is through the continuous engagement of civil society in this process, through shaping national positions and backing government officials that go to the negotiations, that the voice of these groups will be heard". ${ }^{28}$

Several countries also acknowledge that broader stakeholder participation at the national level strengthens developing countries' voices in international tradenegotiations and can improve their capacity to resist pressures from larger economies to make commitments in the area of trade that go against development or public interests. Experience in Kenya, for instance, demonstrated that civil society input to theM inistry of Trade resulted in Kenya being able to submit timely negotiating proposals to the WTO and thus participate in those negotiations in a meaningful way.

The human rights framework can provide an additional tool for resisting

25. M ariama Williams, Gender M ainstreaming in the M ultilateral Trading System - A Handbook for Policy-M akers and Other Stakeholders (London: Commonwealth Secretariat, 2003).

26. OHCHR (op. cit., note 12).

27. 3D -> Trade - Human Rights - Equitable E conomy \& Rights \& Democracy (op. cit., note 21).

28. Quoted in David Ddamilura \& Halima Noor Abdi, Civil Society and the WTO: Participation in National Trade Policy Design in U ganda and Kenya (London: Cafod Trade J ustice Campaign, 2003). 
pressures to agree to trade rules that would reduce flexibility and policy space to protect the public interest and human rights. Indeed, developing countries could, in trade negotiations, use their human rights obligations as a shield to protect them from engaging in liberalization commitments that would reduce their ability to protect human rights. Brazil did this from 2001, through introducing a series of resolutions on access to medicines in the U N C ommission on Human Rights. These resolutions were part of a succesfful global strategy that Brazil spearheaded to achieve recognition of access to medicines as a human right, and which supported developing countries' efforts in theW TO to ensure recognition of their right to make low-cost generic drugs available to their populations. ${ }^{29}$

$\mathrm{H}$ uman rights advocates could make better use of international human rights mechanisms such as the $U N$ human rights treaty bodies in support of national work to ensure that countries' policies on international trade support human rights. Treaty body members occasionally raise trade-related issues ${ }^{30}$ but not in a concerted way, and rarely as part of a strategy to address a specific trade-related human rights concern.

$\mathrm{H}$ uman rights concerns about lack of transparency and participation in trade policy are shared by development groups such as Focus on the G lobal South and 0 xfam, with environmental groups such as the Center for International Environmental Law (CIEL) and with women's groups such as the International Gender and Trade N etwork (IGTN). Yet, although these groups occasionally refer to human rights, few actually apply the human rights framework in support of their work on trade. Human rights advocates could significantly move the public interest agenda in trade forwards by demonstrating the unique usefulness of international human rights monitoring and accountability mechanisms to other public interest advocates.

Indeed, given that human rights advocates share many concerns with other public interest advocates, the best way to ensure human rights are truly mainstreamed in international trade policy is for human rights groups to make their energy and expertise known to other public interest advocates and join forces with them to achieve international trade and traderules, including those developed and applied through the World Trade O rganization, that support rather than threaten human rights.

29. See C. Dommen, "WTO and Human Rights Bodies Reach Out to E ach Other", in Between Trade and Sustainable Development ( B ridges, year 7, n. 3, A pril 2003). Available at <www.ictsd.org/monthly/ archive.htm>. Last access on 7 September 2005.

30. See <www.3dthree.org > for a list of trade-related issues considered by UN human rights treaty bodies. 